\title{
Molecular neurodegeneration: basic biology and disease pathways
}

\author{
Robert Vassar ${ }^{* *}$ and Hui Zheng ${ }^{2}$
}

\begin{abstract}
The field of neurodegeneration research has been advancing rapidly over the past few years, and has provided intriguing new insights into the normal physiological functions and pathogenic roles of a wide range of molecules associated with several devastating neurodegenerative disorders, including Alzheimer's disease, Parkinson's disease, amyotrophic lateral sclerosis, frontotemporal dementia, Huntington's disease, and Down syndrome. Recent developments have also facilitated initial efforts to translate preclinical discoveries toward novel therapeutic approaches and clinical trials in humans. These recent developments are reviewed in the current Review Series on "Molecular Neurodegeneration: Basic Biology and Disease Pathways" in a number of state-of-the-art manuscripts that cover themes presented at the Third International Conference on Molecular Neurodegeneration: "Basic biology and disease pathways" held in Cannes, France, September, 2013.
\end{abstract}

\section{Text}

In September 2013, the Third International Conference on Molecular Neurodegeneration: "Basic biology and disease pathways" was held in Cannes, France. The three-day conference brought together scientists from around the world to present and discuss the results of their most recent research on the normal physiological functions and pathological mechanisms of molecular pathways that are relevant to neurodegenerative diseases (Figure 1). The current thematic review series in the journal, entitled "Molecular Neurodegeneration: Basic Biology and Disease Pathways", is intended to represent not only the scientific findings presented during the conference, but to also reflect the state-of-the-art in a given field. The review series will consist of a "rolling submission" format in which manuscripts by presenters at the conference will appear at regular intervals in the journal.

The conference covered a wide array of topics concerning neurodegeneration at the genetic, molecular, cellular, physiological, behavioral, and systems levels, and with a translational perspective of moving discoveries from preclinical models into human clinical

\footnotetext{
* Correspondence: r-vassar@northwestern.edu

'Northwestern University, Feinberg School of Medicine, Chicago, IL, USA Full list of author information is available at the end of the article
}

trials. Sessions discussed the following areas of neurodegeneration research:

- The genetics of $\mathrm{AD}$ and other neurodegenerative diseases

- The structure and normal physiological functions of molecules involved in neurodegeneration

- Novel molecular mechanisms of AD, PD, ALS, FTD, DS, and HD

- Mechanisms of neurotoxicity in $\mathrm{PD}, \mathrm{AD}$ and other tauopathies

- Novel therapeutic approaches for neurodegenerative diseases

Molecular mechanisms of neurodegeneration were dominant themes of the conference. Some highlights included novel insights into $\mathrm{AD}$ pathogenesis provided by genetic analyses revealing new $\mathrm{AD}$ risk factor genes like CD33 and TREM2 involved in innate immunity [1-4]. Deeper knowledge of the structures and normal physiological functions of APP and the $\alpha$-, $\beta$ - and $\gamma$-secretase enzymes that process $\mathrm{APP}$ is assisting the development of disease-modifying AD therapies that target the neurotoxic $\mathrm{A} \beta$ peptide [5-9]. Intriguing studies have revealed new molecules involved in neurodegeneration, like C9ORF72 in ALS and FTD, and begin to shed light on their pathogenic roles [10-12]. New insights into the prion-like spread of $A \beta$ and tau pathologies in $\mathrm{AD}$ and $\alpha$-synuclein in $\mathrm{PD}$ have also been made 


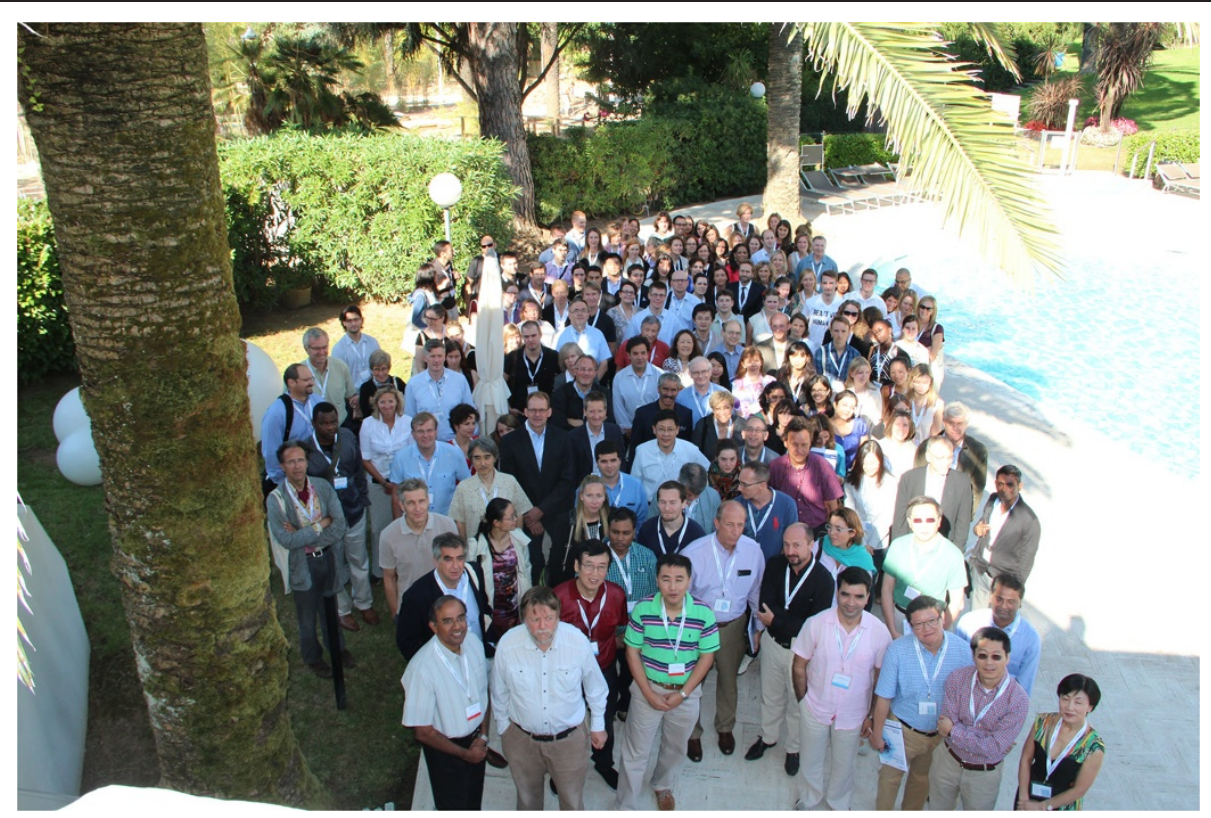

Figure 1 The Third International Conference on Molecular Neurodegeneration: "Basic biology and disease pathways" - Cannes, France. The Conference was attended by 179 delegates from around the world to present and discuss the latest research on normal physiological functions and pathological mechanisms of molecular pathways that are relevant to neurodegenerative diseases.

[13-15]. Additionally, innovative studies of mechanisms of neurotoxicity have revealed roles for micro-RNAs, transcription factors, and trafficking molecules in $\mathrm{AD}$ [16-20]. Novel therapies based on many of these discoveries are also in development, like anti-tau antibodies for $\mathrm{AD}$ and other tauopathies [14].

In summary, this review series aims to encapsulate the themes discussed at the Third International Conference on Molecular Neurodegeneration and provide state-of-the-art knowledge of a wide range of fields in neurodegeneration research. It is the hope of the editors that the knowledge conveyed in the review series will provide quality information to readers and stimulate further scientific advances in molecular neurodegeneration that may someday bring an end to these devastating neurodegenerative disorders.

\section{Abbreviations}

Aß: Beta-amyloid; AD: Alzheimer's disease; ALS: Amyotrophic lateral sclerosis; APP: Amyloid precursor protein; C9ORF72: Chromosome 9 open reading frame 72; CD33: Cluster of differentiation 33; DS: Down syndrome; FTD: Frontotemporal dementia; HD: Huntington's disease; PD: Parkinson's disease; TREM2: Triggering receptor expressed on myeloid cells 2.

\section{Acknowledgements}

We thank the editors of Molecular Neurodegeneration for the invitation for this review series, and particularly the authors of the review manuscripts for their efforts. We further want to express our thanks to all the speakers and participants of the Third International Conference on Molecular Neurodegeneration, who are too numerous to mention by name.

\section{Author details}

'Northwestern University, Feinberg School of Medicine, Chicago, IL, USA.

Baylor College of Medicine, Houston, Tx, USA.
Received: 10 September 2014 Accepted: 11 September 2014 Published: 23 September 2014

\section{References}

1. Tanzi RE: The genetics of Alzheimer disease. Cold Spring Harbor Perspect Med 2012, 2(10). Epub 2012/10/03. doi:10.1101/cshperspect.a006296. PubMed PMID: 23028126.

2. Griciuc A, Serrano-Pozo A, Parrado AR, Lesinski AN, Asselin CN, Mullin K, Hooli B, Choi SH, Hyman BT, Tanzi RE: Alzheimer's disease risk gene CD33 inhibits microglial uptake of amyloid beta. Neuron 2013, 78(4):631-43. doi:10.1016/j.neuron.2013.04.014, PubMed PMID: 23623698, PubMed Central PMCID: PMC3706457.

3. Guerreiro R, Wojtas A, Bras J, Carrasquillo M, Rogaeva E, Majounie E, Cruchaga C, Sassi C, Kauwe JS, Younkin S, Hazrati L, Collinge J, Pocock J, Lashley T, Williams J, Lambert JC, Amouyel P, Goate A, Rademakers R, Morgan K, Powell J, St GeorgeHyslop P, Singleton A, Hardy J: Alzheimer Genetic Analysis G. TREM2 variants in Alzheimer's disease. N Engl J Med 2013, 368(2):117-27.

4. Naj AC, Jun G, Beecham GW, Wang LS, Vardarajan BN, Buros J, Gallins PJ, Buxbaum JD, Jarvik GP, Crane PK, Larson EB, Bird TD, Boeve BF, GraffRadford NR, De Jager PL, Evans D, Schneider JA, Carrasquillo MM, ErtekinTaner N, Younkin SG, Cruchaga C, Kauwe JS, Nowotny P, Kramer P, Hardy J, Huentelman MJ, Myers AJ, Barmada MM, Demirci FY, Baldwin CT, et al: Common variants at MS4A4/MS4A6E, CD2AP, CD33 and EPHA1 are associated with late-onset Alzheimer's disease. Nat Genet 2011, 43(5):436-41. Epub 2011/04/05. doi:10.1038/ng.801. PubMed PMID: 21460841.

5. Muller UC, Zheng H: Physiological functions of APP family proteins. Cold Spring Harbor Perspect Med 2012, 2(2):a006288. doi:10.1101/Cshperspect.a006288, PubMed PMID: 22355794, PubMed Central PMCID: PMC3281588.

6. Renzi F, Zhang X, Rice WJ, Torres-Arancivia C, Gomez-Llorente Y, Diaz R, Ahn K, Yu C, Li YM, Sisodia SS, Ubarretxena-Belandia I: Structure of gamma-secretase and its trimeric pre-activation intermediate by single-particle electron microscopy. J Biol Chem 2011, 286(24):21440-9. doi:10.1074/jbc.M110.193326, PubMed PMID: 21454611, PubMed Central PMCID: PMC3122203.

7. Vassar R, Kuhn PH, Haass C, Kennedy ME, Rajendran L, Wong PC, Lichtenthaler SF: Function, therapeutic potential and cell biology of BACE proteases: current status and future prospects. J Neurochem 2014, doi:10.1111/jnc.12715. PubMed PMID: 24646365. 
8. Chami L, Checler F: BACE1 is at the crossroad of a toxic vicious cycle involving cellular stress and beta-amyloid production in Alzheimer's disease. Mol Neurodegener 2012, 7:52. doi:10.1186/1750-1326-7-52, PubMed PMID: 23039869, PubMed Central PMCID: PMC3507664.

9. Walter J, van Echten-Deckert G: Cross-talk of membrane lipids and Alzheimerrelated proteins. Mol Neurodegener 2013, 8:34. doi:10.1186/1750-1326-8-34, PubMed PMID: 24148205, PubMed Central PMCID: PMC4016522.

10. Meyer K, Ferraiuolo L, Miranda CJ, Likhite S, McElroy S, Renusch S, Ditsworth D, Lagier-Tourenne C, Smith RA, Ravits J, Burghes AH, Shaw PJ, Cleveland DW, Kolb SJ, Kaspar BK: Direct conversion of patient fibroblasts demonstrates non-cell autonomous toxicity of astrocytes to motor neurons in familial and sporadic ALS. Proc Natl Acad Sci U S A 2014, 111(2):829-32. doi:10.1073/pnas.1314085111, PubMed PMID: 24379375; PubMed Central PMCID: PMC3896192.

11. Ling SC, Polymenidou M, Cleveland DW: Converging mechanisms in ALS and FTD: disrupted RNA and protein homeostasis. Neuron 2013, 79(3):416-38, doi:10.1016/jneuron.2013.07.033, PubMed PMID: 23931993.

12. Xu ZS: Does a loss of TDP-43 function cause neurodegeneration? Mol Neurodegener 2012, 7:27. doi:10.1186/1750-1326-7-27, PubMed PMID: 22697423, PubMed Central PMCID: PMC3419078.

13. Jucker $M$, Walker LC: Self-propagation of pathogenic protein aggregates in neurodegenerative diseases. Nature 2013, 501(7465):45-51. 10.1038/ nature12481, PubMed PMID: 24005412, PubMed Central PMCID: PMC3963807.

14. Yanamandra K, Kfoury N, Jiang H, Mahan TE, Ma S, Maloney SE, Wozniak DF, Diamond MI, Holtzman DM: Anti-tau antibodies that block tau aggregate seeding in vitro markedly decrease pathology and improve cognition in vivo. Neuron 2013, 80(2):402-14. 10.1016/j. neuron.2013.07.046, PubMed PMID: 24075978; PubMed Central PMCID: PMC3924573.

15. Guo JL, Covell DJ, Daniels JP, Iba M, Stieber A, Zhang B, Riddle DM, Kwong LK, Xu Y, Trojanowski JQ, Lee VM: Distinct alpha-synuclein strains differentially promote tau inclusions in neurons. Cell 2013, 154(1):103-17. doi:10.1016/j.cell.2013.05.057, PubMed PMID: 23827677; PubMed Central PMCID: PMC3820001

16. Lau P, Bossers K, Janky R, Salta E, Frigerio CS, Barbash S, Rothman R, Sierksma AS, Thathiah A, Greenberg D, Papadopoulou AS, Achsel T, Ayoubi T, Soreq H, Verhaagen J, Swaab DF, Aerts S, De Strooper B: Alteration of the microRNA network during the progression of Alzheimer's disease. EMBO Mol Med 2013, 5(10):1613-34. doi:10.1002/emmm.201201974, PubMed PMID: 24014289, PubMed Central PMCID: PMC3799583.

17. Duplan E, Giaime E, Viotti J, Sevalle J, Corti O, Brice A, Ariga H, Qi L, Checler F, da Alves Costa C: ER-stress-associated functional link between Parkin and DJ-1 via a transcriptional cascade involving the tumor suppressor $\mathrm{p} 53$ and the spliced X-box binding protein XBP-1. J Cell Sci 2013, 126(Pt 9):2124-33.

18. Wang X, Zhao Y, Zhang X, Badie H, Zhou Y, Mu Y, Loo LS, Cai L, Thompson RC, Yang B, Chen Y, Johnson PF, Wu C, Bu G, Mobley WC, Zhang D, Gage FH, Ranscht B, Zhang YW, Lipton SA, Hong W, Xu H: Loss of sorting nexin 27 contributes to excitatory synaptic dysfunction by modulating glutamate receptor recycling in Down's syndrome. Nat Med 2013, 19(4):473-80. doi:10.1038/nm.3117, PubMed PMID: 23524343; PubMed Central PMCID: PMC3911880.

19. Buggia-Prevot V, Fernandez CG, Riordan S, Vetrivel KS, Roseman J, Waters J, Bindokas VP, Vassar R, Thinakaran G: Axonal BACE1 dynamics and targeting in hippocampal neurons: a role for Rab11 GTPase. Mol Neurodegener 2014, 9(1):1. doi:10.1186/1750-1326-9-1, PubMed PMID: 24386896; PubMed Central PMCID: PMC4031619.

20. Buggia-Prevot V, Fernandez CG, Udayar V, Vetrivel KS, Elie A, Roseman J, Sasse VA, Lefkow M, Meckler X, Bhattacharyya S, George M, Kar S, Bindokas VP, Parent AT, Rajendran L, Band H, Vassar R, Thinakaran G: A function for EHD family proteins in unidirectional retrograde dendritic transport of BACE1 and Alzheimer's disease Abeta production. Cell Rep 2013, 5(6):1552-63. do:10.1016/j.celrep.2013.12.006, PubMed PMID: 24373286; PubMed Central PMCID: PMC3932704.

doi:10.1186/1750-1326-9-34

Cite this article as: Vassar and Zheng: Molecular neurodegeneration: basic biology and disease pathways. Molecular Neurodegeneration 2014 9:34.

\section{Submit your next manuscript to BioMed Central and take full advantage of:}

- Convenient online submission

- Thorough peer review

- No space constraints or color figure charges

- Immediate publication on acceptance

- Inclusion in PubMed, CAS, Scopus and Google Scholar

- Research which is freely available for redistribution 